\title{
Eosinophilic pancreatitis versus pancreatitis associated with eosinophilic gastroenteritis - a systematic review regarding clinical features and diagnosis
}

\author{
LARISA PINTE ${ }^{1}$, CRISTIAN BĂICUȘ ${ }^{1,2}$ \\ ${ }^{1}$ Internal Medicine Department, Colentina Clinical Hospital, Bucharest, Romania \\ ${ }^{2}$ Carol Davila University of Medicine and Pharmacy, Bucharest, Romania
}

\begin{abstract}
Background. Over the past years, eosinophil infiltration involving the gastrointestinal tract and pancreas leading to eosinophilic pancreatitis, eosinophilic gastroenteritis and hypereosinophilic syndrome has been reported in the literature.

We aimed to analyze and compare the features involving patients with eosinophilic pancreatitis and pancreatitis associated with eosinophilic gastroenteritis and to determine if there is a connection between the two disorders or if they in fact meet the diagnostic criteria for hypereosinophilic syndrome.

Material and methods. The following search was performed in March 2019 on PubMed (MEDLINE) database using the medical terms "pancreatitis", "eosinophilic pancreatitis", "eosinophilic gastroenteritis" and "hypereosinophilic syndrome".

Results. The search revealed 119 publications from 1970 onwards. A total of 83 papers were excluded, and the remaining 36 publications, consisting in case reports and case series, were analyzed. From 45 patients, 20 subjects with eosinophilic gastroenteritis developed pancreatitis, 20/45 had eosinophilic pancreatitis, and 5/45 hypereosinophilic syndrome involving the pancreas. There was no significant difference regarding clinical, laboratory and imaging features between the three groups, despite the multiple theories that explain the association of pancreatic and gastrointestinal eosinophilic infiltration. Although there was a strong resemblance between the three groups, histological evidence of eosinophilic gastrointestinal infiltration guided the treatment towards a less invasive way, while subjects with eosinophilic pancreatitis underwent pancreatic surgery to exclude potentially malignant lesions.

Conclusion. Although there are various theories that explain pancreatitis development in patients with eosinophilic gastroenteritis, hypereosinophilia diagnostic work-up should be taken into account in all patients with high number of blood eosinophils, even in those with eosinophilic pancreatitis in order to establish the diagnosis using a minimally invasive approach and to apply an adequate treatment.
\end{abstract}

Key words: pancreatitis, eosinophils, esoninophilic pancreatitis, eosinophilic gastroenteritis, hypereosinophilic syndrome, systematic review.

\section{INTRODUCTION}

Over the past years eosinophil infiltration involving the gastrointestinal tract (GI) and accessory digestive organs, especially the pancreas and gallbladder has been identified and studied.

Cases of pancreatitis associated with eosinophilic gastroenteritis (EGE) and hypereosinophilic syndrome (HES), although rare, have been reported in the literature since 1970. Also, in some of the cases when tissue histopathological analysis was performed it revealed eosinophilic infiltration in the pancreas. In the last years, another new entity, eosinophilic pancreatitis (EP), still not clearly defined as separate disease, but considered an uncommon type of chronic pancreatitis showed similar characteristics to those described in patients with other eosinophil related diseases.

We aimed to analyze and compare the features involving patients with eosinophilic pancreatitis and pancreatitis associated with eosinophilic gastroenteritis and to determine if there are two independent disorders or if they in fact meet the diagnostic criteria for hypereosinophilic syndrome.

\section{MATERIAL AND METHODS}

The following search was performed in March 2019 on PubMed (MEDLINE) database using the medical terms "pancreatitis", "eosinophilic pancreatitis", "eosinophilic gastroenteritis" and "hypereosinophilic syndrome" (eosinophilic pancreatitis) OR (pancreatitis AND (eosinophilic gastroenteritis OR hypereosinophilic syndrome).

Subjects with increased IgG4 level were excluded, as their association with eosinophilic pancreatic infiltration will be later discussed. 


\section{RESULTS}

The search revealed 119 publications from 1970 onwards. A total of 83 papers: 16 narrative reviews, 18 case reports involving IgG4 related diseases, 43 case reports without evidence of EGE, HES, EP or pancreatitis and 6 papers without abstract or full text were excluded (Fig 1).

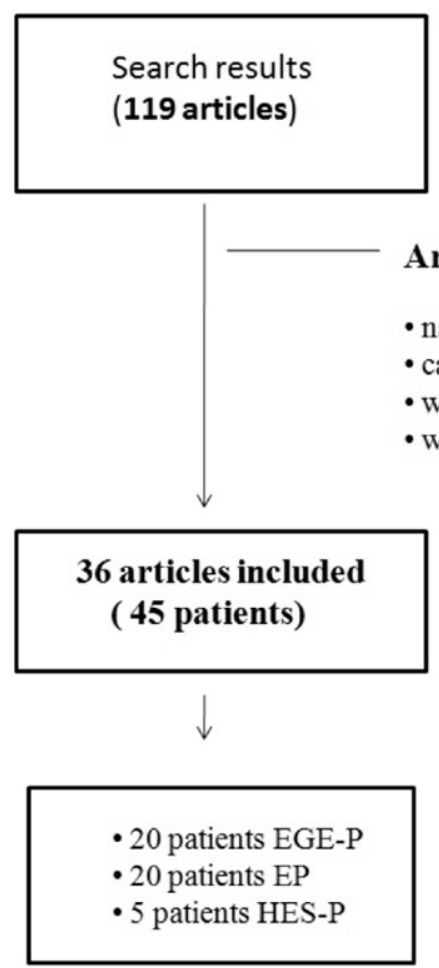

Figure 1. Flow diagram: from PubMed (MEDLINE) search to included studies.

The remaining 36 publications were further classified into 3 groups: patients with eosinophilic gastroenteritis and pancreatitis (EGE-P), hypereosinophilic syndrome and pancreatitis (HES-P) and eosinophilic pancreatitis (EP) only.

A total of 45 patients, 25 males and 20 females, with median age 39 years were analyzed both separately and in comparison according to allergy history, clinical, laboratory, imaging and histopathological features involving the duodenum and pancreas, as well as disease evolution and relapse frequency.

\section{EGE and pancreatitis group (EGE-P)}

There have been reports of EGE associating pancreatitis during its evolution. We identified a total of 20 patients diagnosed with EGE and either increased pancreatic enzymes or history of acute pancreatitis of unknown etiology. Males and females with median age 38 (range 17-74 years) are equally affected. All patients had high eosinophil blood count, but less than half (7/20) had increased IgE levels.

History of allergy was reported in 8 cases: asthma $(3 / 8)[1,2]$, rhinitis $(1 / 8)$ [3], pet allergy
(1/8) [4], food allergies involving cow's milk (2/3) $[5,6]$ and egg allergy $(1 / 3)[7]$, as well as association of allergic diseases (asthma, rhinitis and food allergy) $(1 / 8)[5]$.

Overall abdominal pain was the most frequent symptom (19/20), followed by nausea/vomiting $(12 / 20)$, weight loss $(10 / 20)$ and diarrhea $(7 / 20)$.

Patients with abdominal pain also experienced at least one additional symptom: diarrhea, nausea/ vomiting and weight loss in 3/19 cases[1], nausea/ vomiting and weight loss $4 / 19[5,6,8,9]$, diarrhea and nausea/vomiting $3 / 19[7,10,11]$ or only abdominal pain associated with weight loss $(2 / 19)$ $[2,12]$, nausea/vomiting $(2 / 19)[1,4]$ and diarrhea $(1 / 19)$ [3]. Jaundice $(5 / 20)$ [2, 6, 9, 13], deep vein thrombosis $(1 / 20)$ [11], history of lipodystrophy at the age of 7 years $(1 / 20)$ [12] and CA125 (1/20) [3] or IL5 $(1 / 20)$ [14] values above the range were also reported. In 8 patients the pain started 3 months or more before the moment of diagnosis. Some of them also had eosinophilic ascites [15] as a sign of gastroenteritis subserosal layer involvement (8/20).

Even though 15/20 had pancreatic enzymes above the limit, only $87 \%(13 / 15)$ of them were 
diagnosed with acute pancreatitis at admission and only in 6 cases MRI or CT scan detected a pancreatic lesion.

$4 / 6$ had a solid lesion in the head of the pancreas $[2,9], 1 / 6$ showed only diffuse enlargement of the pancreas [11], while $2 / 6$ had cystic lesions: one in the pancreatic head [3] and the other in the uncinate process [8].

All 5 patients with jaundice had stenosis of the intrapancreatic portion of the common bile duct $[2,6,9,13,16]$, but only 2 of them associated narrowed main pancreatic duct $[2,9]$. Retained gastric secretions were observed in 4 patients showing features of duodenal $(2 / 20)$ and gastric outlet obstruction $(2 / 20)$.

Despite the fact that 2 patients had a history of diabetes mellitus [2, 12], in 18/20 cases there was a lack of data regarding screening for endocrine and exocrine pancreatic insufficiency.

According to the fact that duodenal involvement in EGE is believed to cause pancreatic duct obstruction, imaging, endoscopic and histological features of the duodenum were analysed. CT scans showed duodenal wall thickening in 12 cases, of which in 8 patients upper endoscopy revealed signs of duodenitis (7/20), papilitis (1/20) [1] and multiple ulcerated nodules $(1 / 20)$.

Histopathological analysis established the diagnosis of EGE after high eosinophilic infiltrates were noticed in the duodenum (15/20 patients), stomach $(11 / 20)$, esophagus $(3 / 20)$, small bowel $(2 / 20)$, colon $(2 / 20)$ and even duodenal papilla $(2 / 20)$.

Besides the GI involvement, surgical biopsies also revealed eosinophilic infiltration in the bone marrow $(2 / 20)$, both kidneys and abdominal lymph nodes $(1 / 20)$, liver $(1 / 20)$ and gallbladder $(1 / 20)$ in $25 \%$ patients, but only in 2 cases HES diagnostic work-up was done $[3,8]$ and according to the authors HES criteria were not met.

Pancreatic tissue samples, obtained from 5 patients during surgery for suspected pancreatic cancer (PC), revealed different stages of fibrosis in all patients, but only 3 of them had eosinophilic pancreatic infiltration. In addition, in two patients besides intra and interlobular fibrosis, lobular atrophy [2] or almost total replacement of pancreatic exocrine glands by fibrosis [12] has been described (Table 1).

Table 1

Duodenal, pancreatic and other organ involvement in EGE-P patients

\begin{tabular}{|c|c|c|c|c|c|c|}
\hline Ref & Age/gender & $\begin{array}{c}\text { Duodenum } \\
\text { involvement }\end{array}$ & GI & $\begin{array}{c}\text { Pancreatic } \\
\text { biopsy }\end{array}$ & $\begin{array}{c}\text { Pancreatic } \\
\text { involvement }\end{array}$ & Organ involvement \\
\hline$[10]$ & $68 / \mathrm{F}$ & Yes & - & No & $?$ & - \\
\hline [5] & $28 / \mathrm{M}$ & Yes & $\mathrm{E}, \mathrm{s}$ & No & $?$ & - \\
\hline [6] & $17 / \mathrm{F}$ & Yes & $\mathrm{S}$ & No & $?$ & - \\
\hline [4] & $35 / \mathrm{F}$ & Yes & $\mathrm{s}$ & No & $?$ & Bone marrow \\
\hline [7] & $25 / \mathrm{F}$ & Yes & - & No & $?$ & - \\
\hline [17] & Adult/F & $?$ & - & $?$ & $?$ & - \\
\hline [11] & $30 / \mathrm{M}$ & Yes & - & No & $?$ & Bone marrow \\
\hline [16] & $59 / \mathrm{F}$ & Yes & $\mathrm{S}$ & $?$ & $?$ & - \\
\hline$[1]$ & $57 / \mathrm{M}$ & Yes & $\mathrm{S}$ & No & $?$ & - \\
\hline [1] & $74 / \mathrm{M}$ & Yes & $\mathrm{S}, \mathrm{c}$ & No & $?$ & - \\
\hline [1] & $43 / \mathrm{M}$ & Yes & $\mathrm{E}, \mathrm{s}, \mathrm{c}$ & No & $?$ & - \\
\hline$[1]$ & $60 / \mathrm{F}$ & Yes + papilla & $\mathrm{E}, \mathrm{s}$ & No & $?$ & - \\
\hline [14] & $27 / \mathrm{M}$ & ? & - & ? & $?$ & - \\
\hline$[2]$ & $18 / \mathrm{M}$ & Yes & - & Yes (surg) EUS & Yes & Liver (bio) \\
\hline [2] & $64 / \mathrm{M}$ & $?$ & $\mathrm{~S}$ & Yes (surg) ERCP & No & gallbladder \\
\hline [3] & $33 / \mathrm{F}$ & $?$ & $\mathrm{~S}$ & $?$ & $?$ & - \\
\hline$[8]$ & $38 / \mathrm{M}$ & No & Peritoneum & $?$ & $?$ & - \\
\hline [12] & $27 / \mathrm{F}$ & Yes +papilla & $\mathrm{sb}$ & Yes (surg) & Yes & - \\
\hline [13] & $40 / \mathrm{F}$ & Yes & $\mathrm{S}, \mathrm{sb}$ & Yes (surg) & Yes & - \\
\hline [9] & $47 / \mathrm{M}$ & Yes & - & Yes (surg) & $?$ & lymph nodes, kidney \\
\hline
\end{tabular}

S: stomach, sb: small bowel, c: colon, surg: surgery, GI: gastrointestinal; EUS: echoendoscopy; ERCP: Endoscopic retrograde cholangiopancreatography.

Until proven otherwise, 5 of the 20 patients with EGE-P were initially diagnosed with pancreatic cancer $(3 / 20)[2,13]$, gastric lymphoma $(1 / 20)[6]$ or polyarteritis nodosa $(1 / 20)[9]$.
Besides supportive measures for pancreatitis episode and conservative treatment in a patient with food allergies [7], 7/20 received corticotherapy (CS) $[1,3,8,11,14,17], 1 / 20$ sodium cromoglycate [1], 
while the remaining patients received in addition to CS: montelukast $(1 / 20)$ [10], Ketotifen $(1 / 20)$ [6] and both histamine and leukotriene receptor antagonist $(1 / 20)$ [5].

A total of $45 \%(9 / 20)$ patients had surgery, either for diagnostic (2/9) or treatment (7/9) [1, 2, $4,9,12,13]$ purposes. Two patients with obstructive jaundice, two with duodenal and gastric outlet obstruction, one with chronic pancreatitis who previously had a subtotal pancreatectomy [12] and other 2 with potentially malignant solid pancreatic lesions underwent curative surgery (Table 2). In addition to surgery 2 patients received corticotherapy $[1,9]$. Diagnostic laparoscopy with gastric fullthickness biopsy [6] and peritoneal biopsy [8] was performed in 2 subjects.

Table 2

Surgical management in patients with EGE-P

\begin{tabular}{|l|l|}
\hline \multirow{2}{*}{$(2 / 20)$ duodenal and gastric outlet obstruction } & $\begin{array}{l}\text { distal gastric resection ad modum Billroth II with gastrojejunostomy and } \\
\text { enteroanastomosis [1,4] }\end{array}$ \\
\hline \multirow{2}{*}{$(2 / 20)$ obstructive jaundice } & antrectomy, gastrojejunal anastomosis and biliary-digestive bypass [2] \\
\cline { 2 - 2 } & Billroth 1 with surgical pancreatic biopsy [13] \\
\hline$(2 / 20)$ pancreatic solid lesions in the head & duodenopancreatectomy [2,9] \\
\hline$(1 / 20)$ pain management & pancreatectomy [12] \\
\hline
\end{tabular}

Most patients (75\%, 15/20), despite the ongoing abdominal pain had only one documented episode of acute pancreatitis, $3 / 20$ had 2 episodes, while one subject with 4 documented acute pancreatitis episodes already showed imaging features suggestive of chronic pancreatitis. In addition, microscopic pancreatic tissue analysis at the moment of diagnosis, revealed features of chronic pancreatitis in 2 patients with weight loss and jaundice, but with only one documented episode of acute pancreatitis, in the absence of significant abdominal pain.

Most of the patients (18/20) treated with CS showed satisfying results, at least for a short time. Two patients, one initially treated with sodium cromoglycate [1] and another who underwent subtotal pancreatic resection [12] did not show significant improvement.

Relapses defined as acute pancreatitis recurrence associated with transient eosinophilia were documented in 3 patients: in one patient while tapering down $\mathrm{CS}$, resolved after Sodium cromoglycate was added to the treatment [1]; in the second at 1 year distance from the first episode as such previous treatment with Prednisone and montelukast was reinstated [10]; and in a third patient with history of lipodystrophy and repeated exploratory laparoscopy for unexplained abdominal pain who initially underwent a subtotal pancreatectomy without abdominal pain resolution, such that after 2 years total pancreatectomy was performed but hemorrhagic complications occurred and the patient died [12]. Only in 3 patients with EGE the diagnosis of eosinophilic pancreatitis was confirmed. Apart from the three patients who had eosinophilic pancreatic infiltration, in most of the cases, in the absence of pancreatic tissue analysis, pancreatitis was believed to be a consequence of duodenal eosinophilic infiltration $(11 / 20)$, eosinophil-induced direct toxic endothelial injury $(1 / 20)$ or food allergy $(1 / 20)$.

\section{Patients with HES and pancreatitis}

Our search revealed only 5 patients with HES and pancreatitis, median age 50 years [18-22], all with increased eosinophil blood count, 3 of them with increased $\operatorname{IgE}$ levels and 1 with history of allergy. Abdominal pain and diarrhea (3/5), nausea/ vomiting (3/5) followed by weight loss $(2 / 5)$ were the most common symptoms.

Of $3 / 5$ patients initially suspected of pancreatic cancer, 2 of them had jaundice and one pyloric narrowing, but data regarding imaging pancreatic features were reported only in one patient who had a cephalic pancreatic mass, causing narrowing in the distal common bile duct, associated with body and tail atrophy.

Although all patients had multiple organ involvement, duodenal eosinophilic infiltration was reported only in $2 / 5$ patients. Pancreatic tissue samples from $4 / 5$ patients, obtained during surgery, EUS-FNA and autopsy revealed eosinophilic infiltration in all patients, in one of them associated with pancreatic fibrosis (Table 3).

Data regarding treatment and evolution were available only in 3 patients. Surgery involving pancreaticoduodenectomy was performed only in one patient, while 2 of them received CS associated with dietary restrictions or biliary stenting. 
Table 3

Organ involvement in patients with HES

\begin{tabular}{|c|c|c|l|}
\hline Ref & Duodenal involvement & Pancreatic involvement & \multicolumn{1}{|c|}{ Other organs } \\
\hline$[18]$ & No & Yes (surg) & rheumatologic, cutaneous, GI \\
\hline$[19]$ & Yes & Yes & $\begin{array}{l}\text { GI, skin, lymph nodes, heart, nerves, } \\
\text { arthritis, pleural effusion }\end{array}$ \\
\hline$[20]$ & $\mathrm{Nd}$ & Yes (EUS) & GI, eosinophilic pneumonia \\
\hline$[21]$ & Yes & Nd & GI \\
\hline$[22]$ & $\mathrm{Nd}$ & Yes (autopsy) & $\begin{array}{l}\text { GI, heart, lungs, bone-marrow, thyroid, } \\
\text { ovaries }\end{array}$ \\
\hline
\end{tabular}

Nd: no data.

It appears that in patients with HES-P, treatment approach should take into account that HES implies multiple organ involvement, even in the absence of significant symptoms, as was the case of a patient initially treated with CS and dietary restriction who died after 3 years; autopsy report showed eosinophil infiltration involving the pancreas, heart, lungs, bone marrow, thyroid, GI and ovaries [22].

\section{Patients with eosinophilic pancreatitis}

Lately, patients with inflammatory infiltrate involving the pancreatic tissue, composed mainly of eosinophils have been classified as a rare form of chronic pancreatitis [23] or recurrent acute pancreatitis [24], eosinophilic pancreatitis (EP).

A total of 20 patients, with median age 39 years, including two fetuses of a Type I Diabetic mother were diagnosed with EP. Gender ratio of 12 males to 8 females might suggest that males have a higher chance of developing EP than females.

$75 \%(15 / 20)$ of the patients had increased eosinophil blood count and 4 of them had either mild allergic symptoms (1/20), shellfish allergy $(1 / 20)$ or asthma $(2 / 20)$ [24-27], while increased IgE levels were reported only in $5 / 20$ patients.

Abdominal pain was the most frequent symptom $(15 / 20,75 \%)[12,24-26,28-35]$, followed by nausea/vomiting $(5 / 20,25 \%)$, weight loss $(2 / 20,10 \%)$, diarrhea $(1 / 20,5 \%)$ and jaundice in $7 / 20$ patients. Apart from one patient who accused recurrent abdominal pain during the previous 18 years, in the rest of the cases pain started shortly before hospital admission.

At the moment of diagnosis pancreatic enzymes above the upper limit of normal were reported only in 7 patients $(47 \%)$ with abdominal pain.

Pancreatic ascites (1/20), dyspnea caused by peritoneal and pleural effusion $(1 / 20)$, diabetes mellitus (2/20) and lipodystrophy (1/20) were also reported.
The diagnosis was established in all subjects using CT scan or MRI, followed by ERCP (6/20) and EUS (4/20) in both patients with and without jaundice but with abnormal pancreatic imaging findings.

In $70 \%$ of cases $(14 / 20)$ imaging tests revealed pathological features involving the pancreas $[24,26$, 28-34, 36]: 8/20 pancreatic head enlargement associated in $6 / 8$ patients with a mass-like lesion and in $1 / 8$ with uncinate process involvement. Less frequently, patients had cysts or pseudocysts localized in the head (3/20) and tail $(1 / 20)$ of the pancreas, or calcifications in the pancreatic head (1/20) and only one $(1 / 20)$ showed diffuse enlargement, suggesting entire pancreatic involvement.

Most subjects (5/20) had a double duct stricture involving the distal common bile duct and pancreatic duct, caused by a solid lesion in the head of the pancreas. Only common bile duct stricture was identified in $4 / 20$ cases, sometimes associated with upstream biliary dilation (2/4) and right hepatic duct strictures (1/4), while main pancreatic duct stenosis was found only in one patient with pancreatic cystic lesion of the tail.

Because pancreatic cancer was suspected in more than half of the patients, pancreatic tissue samples were obtained mostly during surgery $(15 / 20)$, but also after EUS-FNB (2/20), CT guided FNB $(1 / 20)$ and autopsy $(2 / 20)$.

Although all patients had eosinophilic pancreatic tissue infiltration, histologic features in those with solid lesions were different from those with cystic lesions. Samples from patients with solid pancreatic lesions revealed diffuse acinar and interstitial eosinophilic infiltrate, in some cases associated with fibrosis $(2 / 20)$ and even with main pancreatic duct involvement (1/20) [27]; and as the inflammatory process persisted, intralobular fibrosis progressed and atrophied lobules [36] without Langerhans islet involvement [26] were identified. On the other hand, in patients with cystic lesions, increased number of eosinophils infiltrated only the fibrous 
wall of the cyst and the perilesional region causing focal pancreatic tissue atrophy, while the rest of the pancreas was histologically unremarkable [26].

Two cases of EP were fetuses of a Type I Diabetic mother [37, 38], in which autopsy reports showed a different pattern of pancreatic eosinophilic infiltration; it appears that in these two cases eosinophils either surrounded or infiltrated the pancreatic islets of Langerhans, while the exocrine pancreas was relatively spared.

Despite the fact that CT scans showed duodenal wall thickening only in $2 / 20$ patients $[31,35]$ and upper endoscopy revealed duodenitis in one patient [28] and papilitis in three [26, 28, 31], random endoscopic biopsies from the duodenal mucosa revealed eosinophilic infiltration in $40 \%(8 / 20)$ cases. Of the three patients with papilitis identified during endoscopy, only in two the duodenal papilla was infiltrated with eosinophils.

In $9(45 \%)$ patients with EP, eosinophils also infiltrated the gallbladder $(5 / 9)[24,26,29,31]$, common bile duct (3/9) [26, 31],spleen (2/9) [26, 30], liver (1/9) [31], abdominal lymph nodes (4/9) $[26,28,30,31]$, mediastinal lymph nodes (1/9) [26] and bone marrow (1/9) [32]. (Table 4) Only 2 of the 9 patients with multiple organ involvement and other 5 patients only with pancreatic eosinophilic infiltration were further investigated for HES.

Table 4

Patients with EP and other organ involvement

\begin{tabular}{|c|c|c|l|c|}
\hline Ref & Age/gender & $\begin{array}{c}\text { Duodenal } \\
\text { involvement }\end{array}$ & \multicolumn{1}{|c|}{ Other organ involvement } & HES Dx work-up \\
\hline$[28]$ & $14 / \mathrm{M}$ & Yes & Abdominal lymph nodes & Yes \\
\hline$[24]$ & $44 / \mathrm{M}$ & $?$ & Gallbladder & No \\
\hline$[29]$ & $36 / \mathrm{M}$ & Yes + ampulla & Gallbladder & No \\
\hline$[30]$ & $21 / \mathrm{M}$ & Yes + colon & Spleen, abdominal lymph nodes & No \\
\hline$[26]$ & $60 / \mathrm{M}$ & Yes & Spleen, gallbladder, mediastinal lymph nodes & No \\
\hline$[26]$ & $36 / \mathrm{F}$ & Yes & CBD, peripancreatic lymph node & No \\
\hline$[26]$ & $41 / \mathrm{M}$ & Yes & CBD, gallbladder & No \\
\hline$[31]$ & $40 / \mathrm{M}$ & Yes + ampulla & CBD, gallbladder, regional lymph nodes, liver & Yes \\
\hline$[32]$ & $68 / \mathrm{M}$ & $?$ & Bone marrow & \\
\hline
\end{tabular}

CBD: common bile duct.

Most subjects underwent pancreatic surgery: pancreaticoduodenectomy $(7 / 20)[26,27,31,35]$, total pancreatectomy $(1 / 20)$ [26], partial pancreatectomy $(1 / 20)$ [25], pylorus-sparing pancreaticoduodenectomy $(1 / 20)[29]$.

In addition, cholecystectomy was performed in 2 patients [24, 29], gastrojejunostomy and tube cholecystotomy in one due to duodenal obstruction [28], and multiple pancreatic duct stents were placed for pancreatic duct leak in another one [24], while en block distal pancreatectomy and splenectomy followed by Cromoglycate administration [30] was performed in a patient with cystic lesion of the tail. In addition to biliary stenting $(2 / 20)$ and surgery $(1 / 20)$, prednisone, often $40 \mathrm{mg} /$ day, was initiated only in $5 / 20$ patients $(25 \%)[12,28,32,34,36]$.

Despite the fact that pancreatectomy and pancreaticoduodenectomy represented a short-term solution for 2 patients with solid pancreatic lesions, GI symptoms and increased eosinophil blood count reoccurred after 2 or 12 months, suggesting that surgical treatment might not be enough in some patients. However, one patient with bone marrow involvement treated only with CS for a short period of time developed fluctuant eosinophilia, without criteria for pancreatitis after 2 months, such that CS were successfully reinstated.

Given the fact that in most cases abdominal pain was reported shortly before hospital admission and imaging studies revealed potentially severe pancreatic pathology, surgical treatment was performed in most patients even in the absence of a documented pancreatitis episodes thus data regarding relapsing pancreatitis was not gathered.

\section{DISCUSSION}

Both "eosinophilic gastroenteritis" and "eosinophilic pancreatitis" are relatively rare pathologies. A PubMed search revealed 903 articles regarding eosinophilic gastroenteritis, 25 regarding eosinophilic pancreatitis and 2544 regarding hypereosinophilic syndrome.

While both males and females equally developed EGE-P, HES-P and EP affected mostly males, with median age 38 years for patients with EGE-P, 39 years for those with EP and 50 years for patients with HES-P. Increased eosinophil blood count was reported in all subjects with EGE-P and 
HES-P, while in the group with EP only $75 \%$ had hypereosinophilia. History of allergy was more frequent in patients with EGE-P $(40 \% ; 8 / 20)$ in contrast to those with EP $(20 \% ; 4 / 20)$ or HES-P $(20 \% ; 1 / 5)$, while IgE levels were mostly increased in HES-P patients $(60 \%)$ and less often in EP patients $(25 \%)$.

Regarding clinical presentation, abdominal pain was the most frequent GI symptom in all three groups (EGE-P 95\%; EP 75\%; HES-P 60\%), followed by nausea or vomiting (EGE-P 60\%; EP 25\%; HES-P 60\%), while weight loss (EGE-P 50\%; HES-P 40\%; EP 10\%) and diarrhea (EGE-P 35\%; HES-P $60 \%$; EP 5\%), signs of chronic pancreatitis were more frequent in the EGE and HES groups, suggesting that GI symptoms in these two groups are probably a consequence of mucosal eosinophilic infiltration and not of exocrine pancreatic insufficiency.

However, a study from 1985 involving patients with alcohol induced pancreatitis showed that there is a correlation between pain severity and the eosinophilic infiltration percentage [39].

Although there are no data on pancreatic enzymes values or acute pancreatitis episodes in the HES-P group, it seems that those with EGE-P $(75 \% ; 15 / 20)$ had higher pancreatic enzymes more frequently than EP patients $(35 \% ; 7 / 20)$.

Some authors[4][14] proposed that duodenal eosinophilic infiltration causes marked swelling in the duodenal wall layers, sometimes involving the duodenal papilla [40], leading to pancreatic duct obstruction and intrapancreatic enzyme activation and acute pancreatitis; moreover, as the inflammatory process continues patients may develop chronic pancreatitis [41].

While analyzing features involving the duodenum, we discovered that patients with EGE-P, unlike those with EP, showed more frequent imaging (duodenal wall thickening 60\%, 12/20), endoscopic $(40 \%, 8 / 20)$ and histological $(75 \%, 15 / 20)$ evidence of eosinophilic duodenal infiltration. However, $40 \%$ $(8 / 20)$ of the patients with EP have duodenal eosinophilic infiltration despite the fact that only $15 \%(3 / 20)$ are diagnosed with duodenitis after endoscopy and even more only $10 \%(2 / 20)$ of them have duodenal wall thickening on CT scans (Table 5).

Table 5

Comparison between patients with EGE-P, EP and HES-P

\begin{tabular}{|c|c|c|c|}
\hline & EGE-P $(n=20)$ & $\mathbf{E P}(\mathrm{n}=20)$ & HES-P $(n=5)$ \\
\hline Mean age & 38 & 39 & 50 \\
\hline females & $50 \%$ & $40 \%$ & $40 \%$ \\
\hline allergy & $40 \%(8 / 20)$ & $20 \%(4 / 20)$ & $20 \%(1 / 5)$ \\
\hline Eosinophilia & $100 \%(20 / 20)$ & $75 \%(15 / 20)$ & $100 \%(5 / 5)$ \\
\hline IgE & $35 \%(7 / 20)$ & $25 \%(5 / 20)$ & $60 \%(3 / 5)$ \\
\hline Abdominal pain & $95 \%(19 / 20)$ & $75 \%(15 / 20)$ & $60 \%(3 / 5)$ \\
\hline Diarrhoea & $35 \%(7 / 20)$ & $5 \%(1 / 20)$ & $60 \%(3 / 5)$ \\
\hline Nausea/vomiting & $60 \%(12 / 20)$ & $25 \%(5 / 20)$ & $60 \%(3 / 5)$ \\
\hline Weight loss & $50 \%(10 / 20)$ & $10 \%(2 / 20)$ & $40 \%(2 / 5)$ \\
\hline Increased pancreatic enzymes & $75 \%(15 / 20)$ & $35 \%(7 / 20)$ & $\mathrm{Nd}$ \\
\hline Acute pancreatitis & $65 \%(13 / 20)$ & $\mathrm{Nd}$ & $\mathrm{Nd}$ \\
\hline \multicolumn{4}{|l|}{ Pancreatic imaging features } \\
\hline Pancreatic lesions & $30 \%(6 / 20)$ head/body/tail & $70 \%(14 / 20)$ Head/body/tail & $20 \%(1 / 5)$ \\
\hline Solid & $4 / 0 / 0$ & $6 / 0 / 0$ uncinate $(1)$ & $1 / 0 / 0$ \\
\hline Cysts & $1+(1$ uncinate $) / 0 / 0$ & 1/0/1 Pseudocyst in the head $(2 / 20)$ & - \\
\hline CBD stricture only & $15 \%(3 / 20)$ & $20 \%(4 / 20)$ & $20 \%(1 / 5)$ \\
\hline Wirsung stricture only & 0 & $5 \%(1 / 20)$ & - \\
\hline Both CBD and Wirsung stricture & $10 \%(2 / 20)$ & $25 \%(5 / 20)$ & \\
\hline Jaundice & $25 \%(5 / 20)$ & $35 \%(7 / 20)$ & $40 \%(2 / 5)$ \\
\hline Eosinophilic pancreatic infiltration & $15 \%(3 / 20)$ & $100 \%(20 / 20)$ & $80 \%(4 / 5)$ \\
\hline \multicolumn{4}{|l|}{ Duodenal features } \\
\hline Duodenal wall thickening & $60 \%(12 / 20)$ & $10 \%(2 / 20)$ & - \\
\hline Endoscopic features & $40 \%(8 / 20)$ & $15 \%(3 / 20)$ & - \\
\hline Duodenal eosinophilic infiltration & $75 \%(15 / 20)$ & $40 \%(8 / 20)$ & $40 \%(2 / 5)$ \\
\hline Other organ involvement & $20 \%(4 / 20)$ & $45 \%(9 / 20)$ & $100 \%(5 / 5)$ \\
\hline Pancreatic resection & $10 \%(2 / 20)$ & $50 \%(10 / 20)$ & $20 \%(1 / 5)$ \\
\hline HES work-up & $10 \%(2 / 20)$ & $35 \%(7 / 20)$ & $100 \%(5 / 5)$ \\
\hline
\end{tabular}

Nd: no data. 
Also, eosinophilic GI infiltration may be difficult to assess due to the patchy pattern, thus more patients with EP may have duodenal involvement, supporting the theory that acute pancreatitis episodes in patients with EGE might be caused by duodenal inflammation.

CT and MRI scans showed pathological pancreatic features in all three groups $(70 \% \mathrm{EP}$; 30\% EGE-P; 20\% HES-P); most patients had solid lesions situated in the pancreatic head, without significant difference regarding prevalence $35 \%$ EP; 20\% EGE-P; 20\% HES-P). Cystic lesions were less frequent, $10 \%$ in both EP and EGE-P patients, while pseudocysts were reported only in patients with EP.

Both CBD and Wirsung stricture were more frequent in EP (25\%) in contrast with EGE-P patients who had mostly CBD stricture (15\%). However, serum pancreatic enzyme levels did not correlate with pathologic imaging features.

Unlike eosinophilic esophagitis when a count of 15 or more eosinophils per high-powered microscopic field (HPF) establishes the diagnosis [42, 43], until now there is no established consensus for eosinophilic gastroenterocolitis, nor for eosinophilic pancreatic infiltration [44-46] (Table 6).

Table 6

Eosinophils cut-off values reported in eosinophilic gastrointestinal diseases

\begin{tabular}{|l|l|}
\hline & Eosinophilic infiltration \\
\hline Eosinophilic esophagitis (EoE) & $\geq 15$ eosinophils/HPF[42] \\
\hline Eosinophilic gastroenteritis & \\
\hline Stomach & $\geq 25$ eosinophils/HPF [45] \\
Duodenum & $\geq 22$ eosinophils/HPF [44] \\
Colon & $\geq 30$ eosinophils/HPF \\
& (caecum > descending colon) \\
& $>50$ eosinophils/HPF (right colon) \\
& $>35$ eosinophils/HPF (transverse colon) \\
& $>25$ eosinophils/HPF (left colon) [46] \\
\hline
\end{tabular}

Some studies suggested that in healthy patients eosinophils do not infiltrate the pancreas [47].

Besides the three previously described pathologies, eosinophils infiltrating the pancreatic tissue were also reported associated with more common diseases in both human and animal subjects.

In animals and birds eosinophilic infiltration was caused by Strongylus equinus infection [48, 49], Toxocara canis infection [50], hematological disorders such as lymphoma [51, 52] and experimentally induced after injecting purified scorpion toxin [53].

In humans is still difficult to establish the pathogenesis of eosinophilic pancreatitis, but frequent causes for different grades of eosinophilic pancreatic infiltration include food allergy [13, 54], hypersensitivity response to medications such as carbamazepine [55, 56], parasitic infections [57], alcoholic [39] and non-alcoholic chronic pancreatitis, especially with pseudocyst formation $[58,59]$ and pancreatic cancer $[27,60,61]$. Less frequent pathologies such as pancreatic allograft rejection, inflammatory myofibroblastic tumor [24] and histiocytosis $\mathrm{X}$ were also reported $[26,27,62]$.

Studies have shown that scattered eosinophil infiltration is also present in patients with lymphoplasmacytic sclerosing pancreatitis, also known as autoimmune pancreatitis (AIP) type 1, usually characterized by increased IgG4 levels [24, 63-67].

In 2009, Detlefsen et al., while evaluating the usefulness of EUS-FNB in diagnosing AIP, assessed eosinophil infiltration besides granulocytic epithelial lesions, IgG4-positive plasma cells, cellular fibrosis with inflammation, lymphoplasmacytic infiltration and venulitis. They considered more than ten eosinophilic granulocytes/HPF cut-off, and showed that both AIP (62.1\%) and non-AIP chronic pancreatitis patients $(33.3 \%)$ had pancreatic eosinophil infiltration [68].

While a study showed that HES patients can also have increased IgG4 levels [69], some authors incline to consider EP a form of AIP [2, 26, 70, 71].

In fact, the term eosinophilic pancreatitis should be used only when pancreatic tissue samples determine that eosinophils are the predominant inflammatory-cell type.

It appears that clinical and imaging features, sometimes highly suggestive for pancreatic cancer, guided the diagnostic work-up, therefore pancreatic tissue samples, mostly obtained at surgery were analysed in all patients with EP and in only $25 \%$ with EGE-P. More than half (3/5) of the pancreatic samples from patients with EGE-P showed eosinophilic infiltration. In both EGE-P and EP patients, eosinophilic 
pancreatic infiltration resulted more often in solid or cystic focal inflammatory mass formation. There is no different pattern of eosinophilic infiltration in patients with EGE-P and EP, as it seems that in both groups periductal, acinar and septal eosinophilic disposition was discovered.

Another theory, sustained by the fact that some patients had microscopic signs of pancreatic fibrosis at the moment of diagnosis, promotes that eosinophils may cause a direct toxic effect due to cytotoxic and proinflammatory mediators [4]. Also, while dealing with recurrent pancreatitis episodes, in the absence of histological proof of pancreatic tissue eosinophil infiltration, it is more probable to assume that pancreatitis in patients with EGE might be in fact caused by duodenal swelling, rather than eosinophil-induced direct toxic effect.

Regarding the pattern of eosinophilic infiltration, affecting mostly the exocrine pancreatic tissue, patients should probably be tested at least for pancreatic exocrine insufficiency.

A total of 12/45 patients, 3 with EGE, 1 with HES and 8 with EP had both duodenal and pancreatic eosinophil infiltration and 8 of them associated other organ involvement besides GI, but HES diagnostic work-up was done only in one of the EGE-P and EP patients (Table 7).

Table 7

Patients with both duodenal and pancreatic eosinophilic infiltration

\begin{tabular}{|c|c|l|c|}
\hline Ref & Dx & \multicolumn{1}{|c|}{ Other organ involvement } & HES Dx work-up \\
\hline$[2]$ & EGE-P & Liver (biopsy) & no \\
\hline$[12]$ & EGE-P & No & no \\
\hline$[13]$ & EGE-P & No & yes \\
\hline$[28]$ & EP & Abdominal lymph nodes & no \\
\hline$[29]$ & EP & Gallbladder & no \\
\hline$[30]$ & EP & Spleen, abdominal lymph nodes & no \\
\hline$[26]$ & EP & Spleen, gallbladder, mediastinal lymph nodes & no \\
\hline$[26]$ & EP & CBD, peripancreatic lymph node & no \\
\hline$[26]$ & EP & CBD, gallbladder & no \\
\hline$[31]$ & EP & CBD, gallbladder,regional lymph nodes, liver & yes \\
\hline$[35]$ & EP & No & \\
\hline$[19]$ & HES & GI, skin, lymph nodes, heart, nerves, arthritis, pleural effusion & \\
\hline
\end{tabular}

CBD: common bile duct; GI: gastrointestinal.

Although less probable, we might be tempted to assume that in some cases EGE-P might be explained by eosinophil migration from the duodenum into the pancreas or from the pancreas into the duodenum in those with EP [28]. For example, one of the patients had eosinophilic infiltrates in both GI and pancreatic tissue as well as the surrounding structures [31], and another one had dense adhesions around the duodenum involving also the portal vein [12].

However, is difficult to classify patients with EGE presenting with pancreatitis episodes, as well as those with EP and GI involvement, especially when associated with eosinophil blood count above $1500 / \mathrm{mm}^{3}$, as GI or pancreatic infiltration might be the first expression of HES [19].

When dealing with a patient with EGE and pancreatitis, it is important to obtain pancreatic tissue samples, especially in patients with pancreatic lesions, in order to assess eosinophil infiltration. Echoendoscopic pancreatic evaluation along with EUS-FNB or even endoscopic ultrasound-guided through-the-needle microforceps biopsy are safe, minimally invasive methods for diagnosing patients with features suggestive for pancreatic and/or GI eosinophilic infiltration, avoiding unnecessary surgery.

Although corticotherapy was mostly used in EGE-P patients, while most subjects with EP and HES-P underwent surgery, besides multiple GI biopsies and close follow-up, CS should be added at least in those associating other organ involvement.

\section{CONCLUSION}

There is no significant difference regarding clinical, laboratory and imaging features between patients with EGE-P, EP and HES-P. Although there are various theories that explain pancreatitis episodes and pancreatic abnormal imaging features in patients with EGE, hypereosinophilia diagnostic work-up should be taken into account in all patients with high number of blood eosinophils; even in those with eosinophilic pancreatitis in order to establish the diagnosis using a minimally invasive approach and to apply an adequate treatment. 
Introducere. În ultimii ani au apărut din ce în ce mai multe date privind infiltrarea eozinofilelor în ţesutul pancreatic şi peretele

tractului digestiv, cu apariţia pancreatitei eozinofilice, a gastroenteritei eozinofilice şi a sindromului hipereozinofilic. Scopul lucrării este să analizeze şi să compare caracteristicile pancreatitei eozinofilice şi ale pancreatitei asociate cu gastroenterita eozinofilică şi de a determina dacă există o legătură între cele două patologii sau dacă, de fapt, se încadrează în sindromul hipereozinofilic.

Materiale şi metode. In martie 2019 s-a efectuat o căutare în baza de date PubMed (MEDLINE) utilizând termenii medicali „pancreatită”, ,pancreatită eozinofilică ”, , ,gastroenterită eozinofilică ” şi ,, sindrom hipereozinofilic”.

Rezultate. Dintre cele 119 publicatiii din 1970 până în prezent, 83 au fost excluse, iar 45 de pacienţi din cele 36 articole incluse în articol au fost analizaţi. Din cei 45 de pacienţi, 20 au avut unul sau mai multe episoade de pancreatită şi au fost diagnosticaţi cu gastroenterită eozinofilică, 20/45 aveau pancreatită eozinofilică, iar 5/45 sindrom hipereozinofilic care afecta pancreasul. In ciuda teoriilor care explică prezenţa eozinofilelor în ţesutul pancreatic şi în peretele tractului digestiv, nu au existat diferențe semnificative în ceea ce priveşte caracteristicile clinice, biologice şi imagistice între cele trei grupuri de pacienţi. $\mathrm{Cu}$ toate acestea, pacienţii cu pancreatită diagnosticaţi cu gastroenterită eozinofilică au fost trataţi într-un mod mai puţin invaziv, spre deosebire de cei cu pancreatită eozinofilică, la care s-a efectuat pancreatectomie pentru a exclude leziuni potenţial maligne.

Concluzie. Deşi există mai multe teorii care explică apariţia pancreatitei la pacienţii cu gastroenterită eozinofilică, trebuie luate în considerare şi alte cauze de apariţie ale hipereozinofiliei, chiar şi la cei cu pancreatită eozinofilică pentru a stabili diagnosticul prin metode minim invazive şi a aplica un tratament adecvat.

Correspondence to: Larisa Pinte, M.D., Internal Medicine Department, Colentina Clinical Hospital, 19-21 Stefan cel Mare Boulevard, sect 2, 020125 Bucharest, Romania

E-mail: larissa.0806@yahoo.com

Conflict of interest disclosure: The authors state there is no conflict of interest.

Abbreviations: EGE: eosinophilic gastroenteritis, HES: Hypereosinophilic syndrome; EP: eosinophilic pancreatitis; IgG4: Immunoglobulin G4; EGE-P: eosinophilic gastroenteritis associated with pancreatitis; HES-P: hypereosinophilic syndrome associated with pancreatitis; IgE: Immunoglobulin E; CA125: cancer antigen 125; IL5: interleukin-5; GI: gastrointestinal; PC: pancreatic cancer; CS: Corticosteroids; CT: computed tomography; MRI: Magnetic resonance imaging; ERCP: Endoscopic retrograde cholangiopancreatography; EUS: echoendoscopy; EUS-FNB: Endoscopic Ultrasound Fine Needle Biopsy; CBD: common bile duct; AIP: Autoimmune pancreatitis

\section{REFERENCES}

1. SHEIKH, R.A., PRINDIVILLE, T.P., PECHA, R.E., RUEBNER, B.H. Unusual presentations of eosinophilic gastroenteritis: case series and review of literature. World J. Gastroenterol. 2009; 15(17):2156-61.

2. BARTHET, M., HASTIER, P., BUCKLEY, M.J., BERNARD, J.P., SASTRE, B., BARONI, J.L., et al. Eosinophilic pancreatitis mimicking pancreatic neoplasia: EUS and ERCP findings - is nonsurgical diagnosis possible?. Pancreas 1998; 17(4):419-22.

3. ZEGARRA, A., GARCÍA, C., PISCOYA, A., DE LOS RÍOS, R., LUIS PINTO, J., MAYO, N., et al. Eosinophilic enteritis as a rare cause of ascites: case report. Rev. Gastroenterol. Peru no date; 29(3):272-5.

4. LYNGBAEK, S., ADAMSEN, S., ARU, A., BERGENFELDT, M. Recurrent acute pancreatitis due to eosinophilic gastroenteritis. Case report and literature review. JOP 2006; 7(2):211-7.

5. SUZUKI, S., HOMMA, T., KUROKAWA, M., MATSUKURA, S., ADACHI, M., WAKABAYASHI, K., et al. Eosinophilic gastroenteritis due to cow's milk allergy presenting with acute pancreatitis. Int. Arch. Allergy Immunol. 2012; 158 (s1):75-82.

6. ÇAĞLAR, E., KARIŞMAZ, K., DOBRUCALI, A. A case of eosinophilic gastroenteritis mimicking gastric lymphoma associated with pancreatitis due to duodenal involvement. Turk. J. Gastroenterol. 2012; 23(5):585-9. 
7. TSE, K.Y., CHRISTIANSEN, S.C. Eosinophilic gastroenteritis due to egg allergy presenting as acute pancreatitis. Allergy Rhinol. (Providence). 2015; 6(1):80-1.

8. CHANDRASEKAR, T.S., GOENKA, M.K., LAWRENCE, R., GOKUL, B.J., MURUGESH, M., MENACHERY, J. An unusual case of ascites. Indian J. Gastroenterol. 2012; 31(4):203-7.

9. CHRISTOPHER, V., THOMPSON, M.H., HUGHES, S. Eosinophilic gastroenteritis mimicking pancreatic cancer. Postgrad. Med. J. 2002; 78(922):498-9.

10. BAEK, M.S., MOK, Y.M., HAN, W.-C., KIM, Y.S. A patient with eosinophilic gastroenteritis presenting with acute pancreatitis and ascites. Gut Liver 2014; 8(2):224-7.

11. JAVID BHAT, K., BHAT, S., DUTT, K., GUPTA, S., JEELANI SAMOON, H. Chronic diarrhea, eosinophilic ascites, acute pancreatitis and deep venous thrombosis: A case report. Casp. J. Intern. Med. 2014; 5(3):182-5.

12. SMITH, P.M., MORGANS, M.E., ClARK, C.G., LENNARD-JONES, J.E., GUNNLAUGSSON, O., JONASSON, T.A. Lipodystrophy, pancreatitis, and eosinophilia. Gut 1975; 16(3):230-4.

13. VÁZQUEZ RODRÍGUEZ, J.J., SOLETO SÁEZ, E., SÁNCHEZ VEGA, J., LÓPEZ SERRANO, M.C., CERDÁN VALLEJO, A. Pancreatitis and eosinophilic gastroenteritis. Int. Surg. 1973; 58(6):415-9.

14. MAEShimA, A., MURAKAMI, H., SADAKATA, H., SAITOH, T., MATSUSHIMA, T., TAMURA, J., et al. Eosinophilic gastroenteritis presenting with acute pancreatitis. J. Med. 1997; 28(3-4):265-72.

15. PINTE, L., BAICUȘ, C. Causes of eosinophilic ascites - a systematic review. Rom. J. Intern. Med. 2018; 0(0), DOI: 10.2478/ rjim-2018-0041.

16. POLYAK, S., SMITH, T.A., MERTZ, H. Eosinophilic gastroenteritis causing pancreatitis and pancreaticobiliary ductal dilation. Dig. Dis. Sci. 2002; 47(5):1091-5.

17. LE CONNIE, D., NGUYEN, H. Eosinophilic gastroenteritis, ascites, and pancreatitis: a case report and review of the literature. South. Med. J. 2004; 97(9):905-6.

18. BELlAiCHE, G., FONTAINE, H., CHOUDAT, L., LUSINA, D., LEY, G., SLAMA, J.L. Pancreatic involvement, ascites and diarrhea in idiopathic hypereosinophilic syndrome. Gastroenterol. Clin. Biol. 1997; 21(6-7):519-22.

19. EUGÈNE, C., GURY, B., BERGUE, A., QUEVAUVILLIERS, J. Icterus disclosing pancreatic involvement in idiopathic hypereosinophilic syndrome. Gastroenterol. Clin. Biol. 1984; 8(12):966-9.

20. DE MOURA, D.T.H., ROCHA, R.S. DE P., JUKEMURA, J., BRUNALDI, V.O., GUEDES, H.G., TORREZ, F.R.A., et al. A rare non-oncological pancreatic mass: eosinophilic pancreatitis diagnosis through EUS-FNA. Endosc. Int. open 2019; 7(2):E151-E154.

21. BOO, I.I., RISCH, L., HEIJNEN, I.A.F.M., HUBER, A.R. Abdominal pain, indigestion and eosinophilia. Rev. Med. Suisse 2006; 2(57):749-53.

22. O'NEILL, T. Eosinophilic granuloma of the gastro-intestinal tract. Case report and suggested classification. Br. J. Surg. 1970; 57(9):704-8.

23. YOUSSEF, N., FLÉJOU, J.-F. Uncommon types of chronic pancreatitis. Ann. Pathol. 2002; 22(5):387-96.

24. REPPUCCI, J., CHANG, M., HUGHES, S., LIU, X. Eosinophilic Pancreatitis: A Rare Cause of Recurrent Acute Pancreatitis. Case Rep. Gastroenterol. 2017; 11(1):120-126.

25. FLEJOU, J.F., POTET, F., BERNADES, P. Eosinophilic pancreatitis: a rare manifestation of digestive allergy?. Gastroenterol. Clin. Biol. no date; 13(8-9): 731-3.

26. ABRAHAM, S.C., LEACH, S., YEO, C.J., CAMERON, J.L., MURAKATA, L.A., BOITNOTT, J.K., et al. Eosinophilic pancreatitis and increased eosinophils in the pancreas. Am. J. Surg. Pathol. 2003; 27(3):334-42.

27. TIAN, L., FU, P., DONG, X., QI, J., ZHU, H. Eosinophilic pancreatitis: Three case reports and literature review. Mol. Clin. Oncol. 2016; 4(4):559-562.

28. CAY, A., IMAMOGLU, M., COBANOGLU, U. Eosinophilic pancreatitis mimicking pancreatic neoplasia. Can. J. Gastroenterol. 2006; 20(5):361-4.

29. EUSCHER, E., VASWANI, K., FRANKEL, W. Eosinophilic pancreatitis: a rare entity that can mimic a pancreatic neoplasm. Ann. Diagn. Pathol. 2000; 4(6):379-85.

30. BASTID, C., SAHEL, J., CHOUX, R., PAYAN, M.J., SARLES, H. Eosinophilic pancreatitis: report of a case. Pancreas 1990; 5(1):104-7.

31. STEVENS, T., MACKEY, R., FALK, G.W., BENNETT, A., HENDERSON, J.M. Eosinophilic pancreatitis presenting as a pancreatic mass with obstructive jaundice. Gastrointest. Endosc. 2006; 63(3):525-527.

32. SALIBA, W.R., DHARAN, M., BISHARAT, N., ELIAS, M. Eosinophilic pancreatic infiltration as a manifestation of lung carcinoma. Am. J. Med. Sci. 2006; 331(5):274-6.

33. RAKESH, K., BANERJEE, R., GUPTA, R., RAMJI, C., PRADEEP, R., RAO, G.V, et al. Eosinophilic pancreatitis with pseudocyst. Indian J. Gastroenterol. no date; 26(3):136-7.

34. KAKODKAR, S., OMAR, H., CABRERA, J., CHI, K. Eosinophilic Pancreatitis Diagnosed With Endoscopic Ultrasound. ACG Case Reports J. 2015; 2(4):239-241.

35. RYAN, K.G. Eosinophilic infiltration of duodenum and pancreatic head: report of a case studied arteriographically. Surgery $1975 ; 77(2): 321-4$.

36. SONG, J.W., KIM, M.H., SEO, W.J., OH, D.R., KIM, G.D., MOON, S.H., et al. A case of eosinophilic pancreatitis. Korean J. Gastroenterol. 2003; 42(5):444-50.

37. GEORGE, E.R., PATEL, S.S., SEN, P., SULE, N. A Unique Case of Eosinophilic Pancreatitis and Anencephaly in the Fetus of a Type I Diabetic Mother. Gastroenterol. Res. 2011; 4(4):174-176.

38. BARRESI, G., INFERRERA, C., DE LUCA, F. Eosinophilic pancreatitis in the newborn infant of a diabetic mother. Virchows Arch. A. Pathol. Anat. Histol. 1978; 380(4):341-8.

39. KEITH, R.G., KESHAVJEE, S.H., KERENYI, N.R. Neuropathology of chronic pancreatitis in humans. Can. J. Surg. 1985; 28(3): 207-11. 
40. MADHOTRA, R., ELOUBEIDI, M.A., CUNNINGHAM, J.T., LEWIN, D., HOFFMAN, B. Eosinophilic gastroenteritis masquerading as ampullary adenoma. J. Clin. Gastroenterol. 2002; 34(3):240-2.

41. MANOHAR, M., VERMA, A.K., VENKATESHAIAH, S.U., SANDERS, N.L., MISHRA, A. Pathogenic mechanisms of pancreatitis. World J. Gastrointest. Pharmacol. Ther. 2017; 8(1):10-25.

42. DELlON, E.S., GONSALVES, N., HIRANO, I., FURUTA, G.T., LIACOURAS, C.A., KATZKA, D.A. ACG Clinical Guideline: Evidenced Based Approach to the Diagnosis and Management of Esophageal Eosinophilia and Eosinophilic Esophagitis (EoE). Am. J. Gastroenterol. 2013; 108(5):679-692.

43. ZUO, L., ROTHENBERG, M.E. Gastrointestinal eosinophilia. Immunol. Allergy Clin. North Am. 2007; 27(3):443-55.

44. MCCARTHY, A.J., SHEAHAN, K. Classification of eosinophilic disorders of the small and large intestine. Virchows Arch. 2018; 472(1):15-28.

45. LUCENDO, A.J., ARIAS, A. Eosinophilic gastroenteritis: an update. Expert Rev. Gastroenterol. Hepatol. 2012 ; 6(5):591-601.

46. TURNER, K.O., SINKRE, R.A., NEUMANN, W.L., GENTA, R.M. Primary Colonic Eosinophilia and Eosinophilic Colitis in Adults. Am. J. Surg. Pathol. 2017; 41(2):225-233.

47. MANOHAR, M., VERMA, A.K., VENKATESHAIAH, S.U., MISHRA, A. Significance of Eosinophils in Promoting Pancreatic malignancy. J. Gastroenterol. Pancreatol. liver Disord. 2017; 5(1):1-9.

48. BREIDER, M.A., KIELY, R.G., EDWARDS, J.F. Chronic eosinophilic pancreatitis and ulcerative colitis in a horse. J. Am. Vet. Med. Assoc. 1985; 186(8):809-11.

49. PETTY, D.P., LANGE, A.L., VERSTER, A., HATTINGH, J. Necropsies of eight horses infected with Strongylus equinus and Strongylus edentatus. J. S. Afr. Vet. Assoc. 1992; 63(2):66-9.

50. HAYDEN, D.W., KRUININGEN, H.J. Experimentally induced canine toxocariasis: laboratory examinations and pathologic changes, with emphasis on the gastrointestinal tract. Am. J. Vet. Res. 1975; 36(11):1605-14.

51. LA PERLE, K.M.D., PIERCY, R.J., LONG, J.F., BLOMME, E.A.G. Multisystemic, Eosinophilic, Epitheliotropic Disease with Intestinal Lymphosarcoma in a Horse. Vet. Pathol. 1998; 35(2):144-146.

52. BLOMME, E.A.G., FOY, S.H., CHAPPELL, K.H., LA PERLE, K.M.D. Hypereosinophilic Syndrome with Hodgkin's-like Lymphoma in a Ferret. J. Comp. Pathol. 1999; 120(2):211-217.

53. NOVAES, G., CARDOZO, C. DE C., COSTA, N.M., DE FALCO, C.N., DE CARVALHO, M.H., DE QUEIROZ, A.C. Experimental chronic interstitial pancreatitis induced by scorpion toxin in rats. Arq. Gastroenterol. no date; 27(4):187-90.

54. DE DIEGO LORENZO, A., ROBLES FORNIELES, J., HERRERO LÓPEZ, T., COS ARREGUI, E. Acute pancreatitis associated with milk allergy. Int. J. Pancreatol. 1992; 12(3):319-21.

55. HADDAD, R., O’BRIEN, B., EVANS, J., ORR, C. Novel finding of carbamazepine induced gall bladder granulomatous vasculitis. Intern. Med. J. 2014; 44(7):700-3.

56. ROBBIE, M.J., SCURRY, J.P., STEVENSON, P. Carbamazepine-induced severe systemic hypersensitivity reaction with eosinophilia. Drug Intell. Clin. Pharm. 1988; 22(10):783-4.

57. DUTT, A.K., BEASLEY, D., SANDOSHAM, A.A. Eosinophilic granuloma of pancreas caused by Ascaris eggs. Med. J. Malaya $1969 ; 24(2): 158-60$.

58. MANOHAR, M., VERMA, A.K., VENKATESHAIAH, S.U., MISHRA, A. Role of eosinophils in the initiation and progression of pancreatitis pathogenesis. Am. J. Physiol. Liver Physiol. 2018; 314(2):G211-G222.

59. HASHIMOTO, F. Transient eosinophilia associated with pancreatitis and pseudocyst formation. Arch. Intern. Med. 1980; 140(8): 1099-100.

60. HIRATA, J., KOGA, T., NISHIMURA, J., IBAYASHI, H. Pancreatic carcinoma associated with marked eosinophilia: a case report. Eur. J. Haematol. 1987; 39(5):462-6.

61. BEESON, P.B. Cancer and Eosinophilia. N. Engl. J. Med. 1983; 309(13):792-793.

62. FARRIS, A.B., BASTURK, O., ADSAY, N.V. Pancreatitis, Other Inflammatory Lesions, and Pancreatic Pseudotumors. Surg. Pathol. Clin. 2011; 4(2):625-650.

63. BRITO-ZERÓN, P., BOSCH, X., RAMOS-CASALS, M., STONE, J.H. IgG4-related disease: Advances in the diagnosis and treatment. Best Pract. Res. Clin. Rheumatol. 2016; 30(2):261-278.

64. FUJIMOTO, T., IMAEDA, H., TAKAHASHI, K., NISHIDA, A., SHIOYA, M., INATOMI, O., et al. Eotaxin-3 (CCL26) Expression in Human Pancreatic Myofibroblasts. Pancreas 2016; 45(3):420-4.

65. ZEN, Y., HARADA, K., SASAKI, M., SATO, Y., TSUNEYAMA, K., HARATAKE, J., et al. IgG4-related sclerosing cholangitis with and without hepatic inflammatory pseudotumor, and sclerosing pancreatitis-associated sclerosing cholangitis: do they belong to a spectrum of sclerosing pancreatitis?. Am. J. Surg. Pathol. 2004; 28(9):1193-203.

66. NEILD, G.H., RODRIGUEZ-JUSTO, M., WALL, C., CONNOLLY, J.O. Hyper-IgG4 disease: report and characterisation of a new disease. BMC Med. 2006; 4:23.

67. UEHARA, T., HAMANO, H., KAWAKAMI, M., KOYAMA, M., KAWA, S., SANO, K., et al. Autoimmune pancreatitis-associated prostatitis: distinct clinicopathological entity. Pathol. Int. 2008; 58(2):118-25.

68. DETLEFSEN, S., MOHR DREWES, A., VYBERG, M., KLÖPPEL, G. Diagnosis of autoimmune pancreatitis by core needle biopsy: application of six microscopic criteria. Virchows Arch. 2009; 454(5):531-9.

69. TABATA, T., KAMISAWA, T., TAKUMA, K., EGAWA, N., SETOGUCHI, K., TSURUTA, K., et al. Serial changes of elevated serum IgG4 levels in IgG4-related systemic disease. Intern. Med. 2011; 50(2):69-75.

70. SAH, R.P., PANNALA, R., ZHANG, L., GRAHAM, R.P., SUGUMAR, A., CHARI, S.T. Eosinophilia and Allergic Disorders in Autoimmune Pancreatitis. Am. J. Gastroenterol. 2010; 105(11):2485-2491.

71. YAMAMOTO, M., TABEYA, T., NAISHIRO, Y., YAJIMA, H., ISHIGAMI, K., SHIMIZU, Y., et al. Value of serum IgG4 in the diagnosis of IgG4-related disease and in differentiation from rheumatic diseases and other diseases. Mod. Rheumatol. 2012; 22(3):419-425.

Received May $1^{\text {st }} 2019$ 